\title{
Margita Gáborová: Stopy Severu v nemeckojazyčnej tlači Bratislavy v rokoch 1918-1929.
}

Bratislava: Univerzita Komenského v Bratislave, 2019, 144 pages.

Margita Gáborová, Associate Professor of Swedish Literature at Comenius University in Bratislava, has published a book that is based on time-consuming archive research. She decided to chart the reception of Scandinavian literature and culture in the German-language press in Bratislava (Pressburg, Poszony) in the years 1918-1929. To this end she had to plough through a great number of newspapers, journals and magazines, without necessarily having certainty that she would find enough relevant material. The amount of discoveries she presents in the book is not extraordinarily high, yet it does confirm Gáborovás oft-repeated claim that the knowledge of Scandinavian culture was an integral part of the intellectual horizon of the German-speaking population of Bratislava in the given time period.

Bratislava is very suitable for cultural transfer studies, because, at least at the time on which the book focuses, it was a truly multicultural city where both Slovak, Hungarian and German were spoken, and a substantial portion of the inhabitants spoke and read more than just one language. As Gáborová points out, "the German-speaking inhabitants spoke and understood Hungarian well” (39). This multilingualism was an important factor in, for example, absorbing impulses from the works by foreign (including Scandinavian) playwrights that were staged in the Municipal Theater, Bratislava's principal theater house. The theater season and the repertoire were divided into three parts: Slovak, German and Hungarian. Despite the fact that there was no permanent company of German-speaking actors at the Municipal Theater, the theater frequently offered stagings in German, because it regularly hosted guest performances from both Austria and Germany, including the most prestigious theater houses (57). As far as these stagings in German are concerned, the Municipal Theater never lacked theatergoers in the discussed period, quite to the contrary: "the German performances were always sold out" (61).

The initial part of the book consists of theoretical deliberations. The author introduces the reader to the methods and concepts she has found the most useful for her purposes, especially cultural transfer, intercultural communication and reception aesthetics. However, the main significance of Gáborovás contribution rests on the chapters in which she discusses the concrete finds from the German press. In these chapters Gáborová often employs Bernd Kortländer's five reception categories: "transfer", "imitation”, "forms of cultural adaptation", "commentaries" and "productive reception" (14). The periodicals she has researched include Preßburger Zeitung, Grenzbote, Deutsche Zeitung für die Slowakei, Pressburer Presse, Volksstimme, Das Riff, Heimat, Die Rampe and Theaterwoche.

The chapters that are devoted to the concrete analyses show that the contemporary readers of the German press in Bratislava were very well informed about the best-known Scandinavian authors, such as Ibsen, Strindberg, H. C. Andersen, Hamsun and Lagerlöf. Especially Ibsen and Strindberg were regarded as modern classics. At the same time, however, the researched texts also reveal that in the 1920s some of the representatives of the younger generation were no longer so excited about Ibsen and Strindberg, considering them to be out of date $(41,56)$. Despite this, Gáborová concludes, the German press in Bratislava failed to comment on any of the significant contemporary Scandinavian 
writers (134). And although the German printed media in 1928 did devote a number of pages to Henrik Ibsen and Selma Lagerlöf in relation to the former's centenary and the latter's seventieth birthday (108), they paid much more attention to the contemporary events concerning the flight and crash of Umberto Nobile's airship Italia in the Arctic and the fate of Roald Amundsen who died in an airplane during his attempt to find and rescue the airship's crew.

The book is mostly clearly written and well argued. Now and then, however, it is not clear whether what one reads in the text is a statement by Gáborová herself, or by the author of the primary or secondary literature she paraphrases. The most problematic example of the blurring of the distinction between various discourses is on p. 42. Gáborová writes that Ibsen "in his most discussed play Hedda Gabler proclaims the idea of equality between man and woman with these words: 'Marriage should be an intimate connection between two free equal people with equal rights"' ["Vo svojej najdiskutovanejšej dráme Hedda Gablerová proklamuje myšlienku rovnoprávnosti ženy a muža týmito slovami: ,Manželstvo má byṫ intímnym spojením dvoch slobodných rovnoprávnych a rovnocenných ludí”" (42)]. Gáborová quotes the original German sentence in a footnote on the same page: "Die Ehe soll eine innere Verbindung zwischen zwei freien, gleichgestellten und gleichwertigen Menschen sein." The problem is that this sentence is nowhere to be found in the text of Ibsen's play. The sentence is a quote from an article by Käthe Bruns - which Gáborová discusses in the same paragraph - and as such it is, in all probability, Bruns' interpretation of Hedda Gabler. In any case, the statement that Ibsen in Hedda Gabler "proclaims [...] with these words" is simply wrong. It is also a pity that the book did not receive more attention from the editor. It contains a relatively high number of typing errors, for example "Ett dömspel" (45), "Göragn", "Samalde" (51), "seizmofraficky" (53), "radaktor" (70), "Hausková" (74), "parí” [instead of "patrí”] (76) and "anitdiskurz" (113).

Despite these shortcomings, the book offers an interesting look at how the image of Scandinavia was created and shared among the people of Bratislava through the German press. At times this image was superficial and stereotypical, yet at other times it was surprisingly well informed. Gáborová guides the reader well through this part of cultural history. The current academic enviroment usually does not encourage scholars to do painstaking archive research. Therefore the reader should be glad that Margita Gáborová was willing to spend endless hours in archives to research this topic. To some degree, the book also provides an interesting material for comparing the early Czech reception of Scandinavian culture with the Slovak reception. What the Czech and Slovak reception of Scandinavian culture certainly have in common is that a great deal of the Scandinavian influence was filtered through translations, articles, reviews and other texts written in German (whether of German or Austrian provenance), although this filtering seems to have begun to lose its importance earlier in the Czech environment, compared to the Slovak. ${ }^{1}$

\section{Martin Humpál \\ https://doi.org/10.14712/24646830.2021.18}

This work was supported by the European Regional Development Fund project "Creativity and Adaptability as Conditions of the Success of Europe in an Interrelated World" (reg. no.: CZ.02.1.01/0.0/0.0/ 16_019/0000734). 